\title{
Menggali Potensi Keunggulan Bersaing Destinasi Wisata Alam Pegunungan di Lumajang
}

\author{
Hesti Budiwati \\ Program Studi Manajemen, STIE Widya Gama Lumajang \\ Email: hestibudiwati1404@gmail.com
}

https://doi.org/10.30741/adv.v3i2.473

\section{N F O A R T I K E L}

Tanggal masuk :

25 Oktober 2019

Tanggal Revisi :

17 November 2019

Tanggal Diterima :

31 Desember 2019

\section{A B S T R A K}

Penelitian ini bertujuan untuk menentukan potensi keunggulan bersaing dan kelemahan yang menjadi strategi prioritas perbaikan untuk meraih keunggulan pada wisata alam B29 di Lumajang. Wisata alam B29 di Lumajang terletak di kawasan Kecamatan Senduro di Kabupaten Lumajang. Dengan menggunakan tehnik analisis data lean six sigma terhadap 30 responden, penelitian ini menjaring pendapat responden berdasarkan persepsi, harapan dan kepentingan masyarakat yang berkunjung ke wisata alam B29 di Lumajang. Kuesioner terlebih dulu diuji validitas dan reliabilitasnya. Hasil penelitian menemukan bahwa keunggulan yang dimiliki wisata alam B29 terletak pada keramahan masyarakat, keindahan alam dan peluang berpetualang, sedangkan yang menjadi prioritas perbaikan adalah ketersediaan bantuan medis, fasilitas umum, listrik, air bersih dan jaringan komunikasi. Peluang riset selanjutnya memungkinkan untuk dilakukan pada obyek wisata maupun produk lainnya.

Kata kunci : Potensi, Keunggulan Bersaing, Wisata Alam

\begin{abstract}
A B S T R A C T
This study aims to determine the potential for competitive advantage and weaknesses which is a priority improvement strategy to achieve excellence in B29 natural tourism in Lumajang. B29 nature tourism in Lumajang is located in Senduro District in Lumajang. By using lean six sigma data analysis techniques on 30 respondents, this study netted the opinions of respondents based on the perceptions, hopes and interests of the people who visited the natural tourism B29 in Lumajang. The questionnaire was first tested for validity and reliability. The results of the study found that the advantages possessed by B29 nature tourism are located at community friendliness, natural beauty and adventure opportunities, while the priority of improvement is the availability of medical assistance, public facilities, electricity, clean water and communication networks. Future research is expected to be able to research with the same method to find competitive advantage in other objects
\end{abstract}

Keywords : Potency, Competitive Advantage, Natural Tourism 


\section{PENDAHULUAN}

Setiap daerah pasti memiliki keunggulan yang dapat dikembangkan agar dapat bersaing dengan daerah lain. "Keunggulan kompetitif merupakan sistem yang diciptakandan memiliki keunggulan yang berbeda agar tercipta nilai pelanggan yang efisien dan memiliki daya tahan" (Heizer dan Render (2015:33). Keunggulan bersaing setidaknya fokus pada superioritas ketrampilan dan superioritas sumberdaya manusianya. Superior resources merupakan sumber daya yang unik dan unggul sehingga lebih tangible untuk meraih keunggulan. Dukungan masyarakat dalam meraih keunggulan suatu daerah sangat diperlukan untuk meraih kemandirian ekonomi yang juga memiliki manfaat menyelesaikan permasalahan-permasalahan sosial di masyarakat untuk diajak berwirausaha bersama menciptakan keunggulan bersaing di kawasan mereka. Setiap daerah memiliki keunikan yang dapat dimanfaatkan untuk meraih keunggulan bersaing, diantaranya keunikan alam, keunikan budaya, keunikan masyarakat dan keunikan lainnya.

Kabupaten Lumajang yang memiliki gunung Semeru yang berada diwilayahnya sangat diuntungkan dengan kesuburan tanahnya karena keberadaan gunung tersebut. Gunung Semeru juga membuat kabupaten Lumajang memiliki udara yang bersih dan sejuk yang membuat pertumbuhan ekonomi di Lumajang dan sekitarnya sangat terdukung dengan kondisi ini, khususnya kecamatan Senduro yang terletak di kaki Gunung Semeru. Kondisi alam di kawasan Senduro yang unik ini ternyata tidak hanya membawa manfaat pada kesuburan tanahnya tetapi juga mulai bermunculan tempat-tempat destinasi wisata yang menjadi unggulan di kawasan tersebut. Tercatat saat ini yang menjadi salah satu keunggulan adalah wisata alam B29 atau terkenal dengan sebutan negeri di atas awan. Pendapat masyarakat sangat dibutuhkan untuk memberikan masukan apa saja yang menjadi potensi keunggulan bersaing destinasi wisata ini, oleh karena itu diperlukan persepsi, harapan dan kepentingan masyarakat. Untuk mengukur persepsi, harapan dan kepentingan masyarakat Lumajang terhadap destinasi wisata B29 ini akan menggunakan konsep Lean Six Sigma.

Metode yang digunakan untuk menentukan kualitas dan prioritas perbaikan ini akan menggunakan Lean Six Sigma. Lean Six Sigma merupakan konsep yang dirancang untuk perbaikan kinerja (William, 2016). Lean adalah usaha berkelanjutan untuk meningkatkan nilai tambah dan mencegah pemborosan produk yang dapat memuaskan pelanggan (Gasperz, 2007). Mengurangi pemborosan pada setiap tahapan operasional akan menciptakan efisiensi (Yang, 2005). Sasaran Lean Six Sigma ditujukan untuk perbaikan berkelanjutan melalui proses penghapusan proses yang tidak bermanfaat (Wahyuni, 2015:19). Namun demikian Lean Six Sigma ini banyak digunakan untuk membuat prioritas perbaikan pada kualitas pelayanan, maka akan menarik jika konsep ini diterapkan selain untuk menemukan prioritas perbaikan juga untuk menemukan keunggulan bersaing. Lean Six Sigma merupakan kegiatan yang berakibat kualitas kritis yang diberikan pada konsumen yang mengakibatkan waktu pelayanan yang lama pada setiap tahapan dan memberikan kesempatan untuk melakukan efisiensi biaya, mutu, ekuitas dan lead time (George, 2002 dalam Wahyuni dkk, 2015:23).

Sebelumnya juga telah ada penelitian yang menggunakan konsep Lean Six Sigma tetapi dilakukan pada bidang jasa. Variasi implementasi Lean Six Sigma di bidang lainnya seperti di bidang pariwisata belum pernah dilakukan. Oleh karena itu peneliti tertarik untuk menerapkan konsep lean six sigma untuk menemukan keunggulan bersaing maupun kelemahan yang menjadi prioritas perbaikan pada wisata alam B29 di Lumajang. Mengingat teknik lean six sigma yang digunakan sama maka peneliti merujuk pada beberapa penelitian yang meskipun berbeda jenis usaha yang diteliti tetapi masih menggunakan konsep yang sama. Penelitian Asih (2014) yang dilakukan di Koperasi XX di Yogjakarta dengan responden 100 orang, menggunakan Lean Six Sigma memberikan hasil bahwa diperlukan perbaikan kualitas dan kuantitas karyawan, perbaikan standar operasional prosedur, reformasi cara dan peralatan kerja dan layanan untuk pelanggan. Santoso (2006) meneliti tentang peningkatan kualitas layanan jasa yang merupakan alternatif dalam peningkatan kualitas layanan jasa. Perbedaan yang diteliti dalam studi ini adalah perbedaan antara pendapat pihak produsen dengan ekspetasi pelanggan. Budiwati (2016) menerapkan Lean Six 
Sigma untuk menemukan keunggulan dan prioritas perbaikan kualitas layanan perbankan. Penelitian ini menghasilkan layanan yang harus diperbaiki yaitu dibidang keterhandalan dan efisiensi. Penelitian Budiwati (2016) lainnya juga menerapkan Lean Six Sigma pada obyek yang berbeda yaitu produk unggulan batik Lumajang. Penelitian ini berhasil menentukan perbaikan apa yang harus diprioritaskna untu meningkatkan keunggulan bersaing batik Lumajang. Penelitian yang berkesinambungan tentang bagaimana menggali keunggulan bersaing pada destinasi wisata terutama di setiap daerah memunculkan pertanyaan penelitian yang akan dicarikan solusinya yaitu (a) Apa saja potensi keunggulan bersaing yang dimiliki destinasi wisata B29 di Lumajang? dan (b) Apa saja solusi perbaikan terhadap destinasi wisata B29 di Lumajang?

\section{METODE PENELITIAN}

Jenis penelitian ini adalah penelitian deskriptif kualitatif karena bertujuan untuk menentukan predikat pada obyek yang diteliti sesuai dengan keadaannya (Arikunto, 2013:269). Penelitian ini bertujuan untuk menggambarkan wisata alam pegubungan di B29 Lumajang dan menyimpulkan pendapat responden berdasarkan ekspetasi, dan kepentingan masyarakat yang akan digunakan untuk menentukan keunggulan bersaing dan apa saja yang harus dilakukan perbaikan pada wisata pegunungan B29 di Lumajang. Penelitian ini dilakukan terhadap masyarakat maupun pengunjung yang pernah berkunjung di wisata alam B29 di Lumajang. Alasan dipilihnya masyarakat ataupun pengunjung untuk dijaring pendapatnya berdasarkan persepsi, harapan dan kepentingan mereka, agar dapat memberikan masukan untuk perbaikan perbaikan di wisata alam B29 di Lumajang. Mereka akan diberikan kuesioner untuk menjaring pendapat atas keberadaan wisata alam B29 di Lumajang.

Data dalam penelitian ini menurut sumbernya merupakan data ekternal yang dijaring dari responden. Jenis datanya merupan data primer karena diperoleh langsung dari responden pada saat mengisi kuesioner dengan menggunakan skala ordinal. Teknik pengumpulan data adalah dengan menggunakan kuesioner atau daftar pertanyaan yang diberikan kepada responden. Untuk penyebaran kuesioner sebagai bahan penelitian diberikan kepada masyarakat Lumajang maupun pengunjung yang pernah pernah datang di wisata alam B29 di Lumajang. Skor nilai diberikan dalam proses pengukuran data pada setiap jawaban dari pertanyaan pada kuesioner berdasarkan skala Likert dengan pilihan jika jawaban sangat setuju/ selalu/ sangat positif (SS/ SL) diberikan nilai 5, jawaban setuju/ sering/ positif (ST/ SR) diberikan nilai 4, jawaban ragu- ragu/ kadangkadang. Netral (RG/ KS) diberikan nilai 3, jawaban tidak setuju/ hampir tdak pernah/ negative (TS/ TP) diberikan nilai 2 dan jawaban tidak setuju/ hampir tdak pernah/ negative (TS/ TP) diberikan nilai 1 (Sugiyono, 2008:93).

Masyarakat dan pengujung wisata pegunungan B29 di Lumajang menjadi sasaran populasi dalam penelitian ini. Pengambilan sampel menggunakan simple random sampling yang berprinsip memberikan kesempatan yang sama pada semua anggota populasi untuk dijadikan sampel. Penentuan ukuran sampel yang digunakan adalah metode yang dikembangkan oleh Roscoe dalam bukunya Research Methods For Business (1982:253) seperti yang dikutip dalam (Sugiyono, 2015:164), bahwa ukuran sampel yang layak dalam penelitian adalah antara 30 sampai dengan 500. Oleh karena itu jumlah sampel dalam penelitian ini adalah 30 responden. Variabel yang digunakan untuk menentukan keunggulan bersaing dan prioritas perbaikan destinasi wisata B29 ini adalah Atraksi, Fasilitas dan Pelayanan, Aksebilitas, Citra Obyek wisata.

Pendekatan Lean Six Sigma dalam penelitian ini digunakna sebagai tehnik analisis data. Uji instrument terlebih dulu dilakukan dengan menguji validitas dan reliabilitas. Tahap berikutnya dilakukan untuk menentukan keunggulan bersaing dan perbaikan dengan tahapan sebagai berikut: Selanjutnya dilakukan pengolahan data ditujukan untuk menentukan keunggulan bersaing dan prioritas perbaikan berdasarkan perhitungan gap dan penentuan bobot sebagai berikut: (a) Identifikasi Gap Tanpa Bobot, dilakukan dengan menghitung jarak antara nilai ekspetasi dan pendapat responden. Nilai gap yang dihitung adalah nilai beda rata-rata yang didapatkan dari 
perbedaan nilai rata-rata ekspektasi masyarakat dengan nilai rata-rata pendapat masyarakat, (b) Identifikasi Gap Terbobot, dilakukan dengan menghitung rasio kepentingan masyarakat terhadap jumlah kepentingan, nilai gap diperoleh dari hitungan nilai gap tanpa bobot. Gap terbobot diperoleh dari perkalian bobot dan nilai gap, (c) Menentukan Keunggulan Bersaing, dilakukan dengan menyusun diurutkan dari nilai gap yang paling kecil ke nilai gap terbobot yang paling besar, (d) Menentukan prioritas perbaikan, dilakukan dengan menyusun diurutkan dari nilai gap yang paling besar ke nilai gap terbobot yang paling kecil.

\section{HASIL DAN PEMBAHASAN}

Wisata alam pegunungan B29 di Lumajang yang juga dikenal sebagai negeri di atas awan terletak di Desa Argosari Kecamatan Senduro Kabupaten Lumajang. Puncak B29 masih merupakan tempat wisata baru yang memiliki pemandangan yang bagus, Puncak B29 dengan ketinggian 2.900 mdpl dari permukaan laut ini memperoleh predikat puncak paling tinggi di Bromo. Wisata alam pegunungan B29 dikenal keindahannya karena terasa seperti di atas awan serta keindahan matahari terbitnya. Lokasi wisata ini merupakan sebuah lereng gunung dengan ketinggian 2900 meter diatas permukaan laut. Puncak B29 merupakan puncak yang paling tinggi dan berada di kawasan gunung Bromo. Pemandangan yang indah disertai suhu udara yang dingin serta hamparan ciri khas gunung dan juga padang pasir menjadi pemandangan yang menarik di lokasi wisata ini. Rute yang menantang dengan jalur yang berliku sepanjang perjalanan dapat memunculkan adrenalin. Keindahan puncak B29 Lumajang ini diperoleh dari pemandangan yang bisa dilihat di puncak. Lokasi kawasan B29 ini juga terdiri dari kawasan perkebunan argosari yang membentuk barisan pegunungan mahameru, serta puncak dan pemandangan pasir bromo. Sunrise dan sunset juga menjadi suguhan pemandangan alam yang sangat indah untuk disaksikan di lokasi ini. Dari puncak B29, juga dapat disaksikan keindahan Tosari Pasuruan, Sukapura Probolinggo.

Jalur menuju Puncak wisata pegunungan B29 bisa ditempuh dengan menggunakan kendaraan bermotor. Jika dari arah Surabaya bisa ditempuh dengan berkendara langsung menuju kota Lumajang, dari kota Lumajang ke puncak B29 berjarak 40 km yang ditempuh kurang lebih 2 jam perjalanan dengan kondisi jalan beraspal. Dari pusat kota Lumajang menuju Kecamatan Senduro menuju Desa Argosari. Di desa Argosari akan disambut dengan gerbang selamat datang "Kawasan Wisata B29 Desa Argosari Kecamatan Senduro, Kabupaten Lumajang”. Perjalanan selanjutnya menggunakan jasa ojek yang tersedia dan bisa disewa, dan jika menggunakan motor sendiri bisa langsung menuju puncak B29 dengan kondisi jalan menanjak dengan pemandangan yang indah. Responden dalam penelitian ini adalah masyarakat Lumajang maupun dari luar Lumajang yang pernah berkunjung di Wisata Alam B29 di Lumajang. Jumlah sampel dalam penelitian ini sebanyak 30 responden. Berikut adalah data-data yang akan disajikan yang berkaitan dengan gambaran umum responden :

Tabel 2. Deskripsi Responden Berdasarkan Gender

\begin{tabular}{clcc}
\hline No. & \multicolumn{1}{c}{ Jenis Kelamin } & Jumlah & \% \\
\hline 1. & Laki-Laki & 19 & $63,3 \%$ \\
2. & Perempuan & 11 & $36,7 \%$ \\
& Jumlah & 30 & $100 \%$ \\
\hline
\end{tabular}

Sumber data : Hasil Kuesioner Diolah, 2018.

Data di atas menunjukkan bahwa dari 30 responden yang terpilih menjadi responden penelitian ini menunjukkan prosentase tertinggi yang berkunjung ke Wisata Alam B29 di Lumajang didominasi responden bergender laki-laki.

Tabel 3. Deskripsi Responden Berdasarkan Jenis Pekerjaan

\begin{tabular}{llcr}
\hline No. & Jenis Pekerjaan & Jumlah \\
\hline
\end{tabular}




\begin{tabular}{llcc}
\hline 1. & Pegawai & 5 & $26,7 \%$ \\
2. & Karyawan Swasta & 17 & $56,7 \%$ \\
3. & Mahasiswa/Pelajar & 8 & $16,7 \%$ \\
& Jumlah & 120 & $100 \%$ \\
\hline
\end{tabular}

Sumber data : Hasil Kuesioner Diolah, 2018.

Data di atas menunjukkan bahwa dari 30 responden yang terpilih menjadi responden penelitian ini menunjukkan prosentase tertinggi yang berkunjung ke Wisata Alam B29 di Lumajang adalah karyawan swasta diikuti oleh mahasiswa dan pelajar. Persepsi masyarakat atas pernyataan tentang destinasi wisata alam B 29 di Lumajang memberikan nilai rata-rata 3,32 pada harapan masyarakat memberikan nilai rata-rata 4,42 dan pada kepentingan masyarakat memberikan nilai rata-rata 4,47. Pengumpulan data penelitian dilakukan dengan menyebarkan kuesioner kepada 30 responden. Berikutnya data yang terkumpul dianalisis dengan menggunakan software SPSS versi 21 untuk menguji instrument penelitian. Selanjutnya menentukan keunggulan bersaing dan prioritas perbaikan pada destinasi wisata alam pegunungan B29 di Lumajang menggunakan pendekatan Lean Six Sigma.

Hasil pengujian validitas kuesioner terhadap 21 item pernyataan pada destinasi wisata alam B29 di Lumajang, memberikan hasil bahwa semua item pernyataan pada masing-masing variabel memiliki $\mathrm{r}$ hitung> 0,3 dengan tingkat signifikan di bawah 5\%, maka disimpulkan bahwa kuesioner yang digunakan dapat menggali data atau informasi yang diperlukan. Selanjutnya uji reliabilitas dilakukan untuk mengukur sampai sejauh mana kuesioner yang diajukan dapat memberikan hasil yang tidak berbeda. dengan menggunakan rumus Cronbach Alpha. Hasil pengujian reliabilitas kuesioner terhadap 21 item pernyataan pada destinasi wisata alam B29 di Lumajang, memberikan hasil bahwa semua item pernyataan pada masing-masing variabel mempunyai nilai Cronbach's Alpha dengan range nilai masuk kategori cukup reliabel, reliabel dan sangat reliabel. Jadi dapat disimpulkan bahwa kuesioner yang digunakan dalam penelitian ini merupakan kuesioner yang handal.

Pada tahap selanjutnya akan dilakukan perhitungan nilai gap tanpa bobot yaitu dengan mencari selisih antara nilai harapan dengan nilai persepsi masyarakat atas destinasi wisata alam B29 di Lumajang. Nilai gap yang dimaksud adalah nilai gap rata-rata yang diperoleh dari selisih nilai ratarata harapan masyarakat dengan nilai rata-rata persepsi masyarakat atas destinasi wisata alam B29 di Lumajang.

Tabel 4. Perhitungan Nilai Gap Tanpa Bobot destinasi wisata alam B29 di Lumajang

No. Pernyataan $\quad$ Nilai Nilai Nilai




\begin{tabular}{|c|c|c|c|c|}
\hline & & Persepsi & Harapan & Gap \\
\hline 1 & Keindahan alam B29 & 4,30 & 4,70 & $-0,40$ \\
\hline 2 & Peluang berpetualang di B29 & 3,70 & 4,27 & $-0,57$ \\
\hline 3 & Tersedia souvenir B29 & 2,73 & 4,13 & $-1,40$ \\
\hline 4 & Keberadaan budaya lokal di lokasi B29 & 3,67 & 4,43 & $-0,76$ \\
\hline 5 & Jaminan keselamatan pengunjung B29 & 3,20 & 4,57 & $-1,37$ \\
\hline 6 & Ketersediaan informasi yang akurat tentang B29 & 3,33 & 4,37 & $-1,04$ \\
\hline 7 & $\begin{array}{l}\text { Ketersediaan sarana penginapan yang memadai } \\
\text { disekitar B29 }\end{array}$ & 2,83 & 4,27 & $-1,44$ \\
\hline 8 & $\begin{array}{l}\text { Ketersediaan fasilitas umum (toilet, tempat } \\
\text { sampah, tempat ibadah, dll) }\end{array}$ & 2,83 & 4,50 & $-1,67$ \\
\hline 9 & $\begin{array}{l}\text { Ketersediaan tempat istirahat, makan dan } \\
\text { minum }\end{array}$ & 3,40 & 4,37 & $-0,97$ \\
\hline 10 & $\begin{array}{l}\text { Ketersediaan menu makanan yang praktis dan } \\
\text { higienes }\end{array}$ & 3,07 & 4,23 & $-1,16$ \\
\hline 11 & $\begin{array}{l}\text { Ketersediaan listrik, air bersih, jaringan } \\
\text { komunikasi }\end{array}$ & 2,70 & 4,27 & $-1,57$ \\
\hline 12 & Ketersediaan bantuan dan perawatan medis & 2,77 & 4,60 & $-1,83$ \\
\hline 13 & Jalan menuju B29 tersedia dan mudah ditempuh & 3,43 & 4,50 & $-1,07$ \\
\hline 14 & Kualitas jalan menuju B29 & 3,17 & 4,60 & $-1,43$ \\
\hline 15 & Sarana transportasi memadai & 3,33 & 4,23 & $-0,90$ \\
\hline 16 & $\begin{array}{l}\text { Terdapat rambu-rambu penunjuk arah yang jelas } \\
\text { B29 }\end{array}$ & 3,83 & 4,50 & $-0,67$ \\
\hline 17 & Kebersihan tempat wisata B29 & 3,43 & 4,60 & $-1,17$ \\
\hline 18 & $\begin{array}{l}\text { Kebersihan fasilitas umum (toilet, tempat } \\
\text { sampah, ibadah) }\end{array}$ & 3,07 & 4,50 & $-1,43$ \\
\hline 19 & Keramahan ojek sepeda motor ke B29 & 3,30 & 4,30 & $-1,00$ \\
\hline 20 & Keramahan masyarakat sekitar B29 & 4,03 & 4,27 & $-0,24$ \\
\hline 21 & Jaminan keamanan pengunjung di wisata B29 & 3,53 & 4,60 & $-1,07$ \\
\hline
\end{tabular}

Sumber Data : Hasil kuesioner diolah, 2018.

Dari hasil perhitungan nilai gap tanpa bobot sebagaimana ditunjukkan pada tabel diatas maka terlihat bahwa gap terbesar sebesar 1,83 terletak pada pernyataan ke 12 yaitu "ketersediaan bantuan dan perawatan medis". Selanjutnya dilakukan perhitungan gap terbobot yang dihitung dari rasio tingkat kepentingan setiap pernyataan terhadap jumlah tingkat kepentingan, sedangkan nilai gap diperoleh dari perhitungan nilai gap tanpa bobot seperti pada tabel di atas. Gap terbobot merupakan hasil perkalian antara bobot dan nilai gap. Hasil perhitungan gap terbobot sebagai berikut:

Tabel 5. Perhitungan Nilai Gap Terbobot destinasi wisata alam B29 di Lumajang

\begin{tabular}{llllll}
\hline No. & Pernyataan & Tingkat & Bobot & Nilai & Gap \\
\hline
\end{tabular}




\begin{tabular}{|c|c|c|c|c|c|}
\hline & & Kepentingan & & Gap & Terbobot \\
\hline 1 & Keindahan alam B29 & 4,80 & 0,051 & $-0,40$ & $-0,020$ \\
\hline 2 & $\begin{array}{l}\text { Peluang untuk berpetualang di } \\
\text { B29 }\end{array}$ & 3,97 & 0,042 & $-0,57$ & $-0,024$ \\
\hline 3 & Tersedia souvenir B29 & 3,97 & 0,042 & $-1,40$ & $-0,059$ \\
\hline 4 & $\begin{array}{l}\text { Keberadaan budaya lokal di } \\
\text { lokasi B29 }\end{array}$ & 4,27 & 0,046 & $-0,76$ & $-0,035$ \\
\hline 5 & $\begin{array}{ll}\text { Jaminan } & \text { keselamatan } \\
\text { pengunjung B29 } & \end{array}$ & 4,87 & 0,052 & $-1,37$ & $-0,071$ \\
\hline 6 & $\begin{array}{l}\text { Ketersediaan informasi yang } \\
\text { akurat tentang B29 }\end{array}$ & 4,47 & 0,048 & $-1,04$ & $-0,050$ \\
\hline 7 & $\begin{array}{l}\text { Ketersediaan sarana penginapan } \\
\text { yang memadai disekitar B29 }\end{array}$ & 4,30 & 0,046 & $-1,44$ & $-0,066$ \\
\hline 8 & $\begin{array}{l}\text { Ketersediaan fasilitas umum } \\
\text { (toilet, tempat sampah, ibadah) }\end{array}$ & 4,53 & 0,048 & $-1,67$ & $-0,081$ \\
\hline 9 & $\begin{array}{l}\text { Ketersediaan tempat istirahat, } \\
\text { makan dan minum }\end{array}$ & 4,43 & 0,047 & $-0,97$ & $-0,046$ \\
\hline 10 & $\begin{array}{l}\text { Ketersediaan menu makanan } \\
\text { yang praktis dan higienes }\end{array}$ & 4,20 & 0,045 & $-1,16$ & $-0,052$ \\
\hline 11 & $\begin{array}{l}\text { Ketersediaan listrik, air bersih, } \\
\text { jaringan komunikasi }\end{array}$ & 4,43 & 0,047 & $-1,57$ & $-0,074$ \\
\hline 12 & $\begin{array}{l}\text { Ketersediaan bantuan dan } \\
\text { perawatan medis }\end{array}$ & 4,67 & 0,050 & $-1,83$ & $-0,091$ \\
\hline 13 & $\begin{array}{l}\text { Jalan menuju B29 tersedia dan } \\
\text { mudah ditempuh }\end{array}$ & 4,57 & 0,049 & $-1,07$ & $-0,052$ \\
\hline 14 & Kualitas jalan menuju B29 & 4,67 & 0,050 & $-1,43$ & $-0,071$ \\
\hline 15 & Sarana transportasi memadai & 4,40 & 0,047 & $-0,90$ & $-0,042$ \\
\hline 16 & $\begin{array}{l}\text { Terdapat rambu-rambu } \\
\text { penunjuk arah yang jelas B29 }\end{array}$ & 4,50 & 0,048 & $-0,67$ & $-0,032$ \\
\hline 17 & Kebersihan tempat wisata B29 & 4,63 & 0,049 & $-1,17$ & $-0,058$ \\
\hline 18 & $\begin{array}{l}\text { Kebersihan fasilitas umum } \\
\text { (toilet, tempat sampah, tempat } \\
\text { ibadah, dll) }\end{array}$ & 4,60 & 0,049 & $-1,43$ & $-0,070$ \\
\hline 19 & $\begin{array}{l}\text { Keramahan ojek sepeda motor } \\
\text { ke B29 }\end{array}$ & 4,23 & 0,045 & $-1,00$ & $-0,045$ \\
\hline 20 & $\begin{array}{l}\text { Keramahan masyarakat sekitar } \\
\text { B29 }\end{array}$ & 4,50 & 0,048 & $-0,24$ & $-0,012$ \\
\hline 21 & $\begin{array}{l}\text { Jaminan keamanan pengunjung } \\
\text { di wisata B29 }\end{array}$ & 4,80 & 0,051 & $-1,07$ & $-0,055$ \\
\hline
\end{tabular}

Sumber Data : Hasil kuesioner diolah, 2018.

Berdasarkan perhitungan nilai gap terbobot pada tabel di atas maka dapat diketahui keunggulan bersaing dan prioritas perbaikan pada wisata alam B29 di Lumajang. Dimana data akan diurutkan berdasarkan nilai gap terbobot terkecil sampai gap terbobot terbesar. Nilai gap terbobot terkecil diambil sebagai keunggulan bersaing dengan pertimbangan bahwa gap terbobot terkecil berarti tidak terjadi kesenjangan yang tinggi antara persepsi, harapan dan kepentingan masyarakat. Artinya apa yang dipersepsikan sudah sesuai dengan harapan dan kepentingan masyarakat. Sedangkan nilai gap terbobot terbesar diambil sebagai prioritas perbaikan dengan pertimbangan bahwa nilai gap terbobot terbesar berarti terjadi kesenjangan yang tinggi antara persepsi, harapan dan kepentingan masyarakat. Artinya apa yang dipersepsikan tidak sesuai dengan harapan dan kepentingan masyarakat.

Tabel 6. Penentuan Keunggulan Bersaing dan Prioritas Perbaikan Destinasi Wisata Alam B29 di Lumajang 


\begin{tabular}{clcc}
\hline No. & \multicolumn{1}{c}{ Pernyataan } & $\begin{array}{c}\text { Gap } \\
\text { Terbobot }\end{array}$ & $\begin{array}{c}\text { Urutan } \\
\text { Keunggulan }\end{array}$ \\
\hline 1 & Keindahan alam B29 & $-0,020$ & 2 \\
2 & Peluang untuk berpetualang di B29 & $-0,024$ & 3 \\
3 & Tersedia souvenir B29 & $-0,059$ & 14 \\
4 & Keberadaan budaya lokal di lokasi B29 & $-0,035$ & 5 \\
5 & Jaminan keselamatan pengunjung B29 & $-0,071$ & 17 \\
6 & Ketersediaan informasi yang akurat tentang B29 & $-0,050$ & 9 \\
7 & Ketersediaan sarana penginapan yang memadai & $-0,066$ & 15 \\
& disekitar B29 & & \\
8 & Ketersediaan fasilitas umum (toilet, tempat sampah, & $-0,081$ & 20 \\
9 & Kempat ibadah, dll) & $-0,046$ & 8 \\
10 & Ketersediaan tempat istirahat, makan dan minum & $-0,052$ & 10 \\
& higienes & & \\
11 & Ketersediaan listrik, air bersih, jaringan komunikasi & $-0,074$ & 19 \\
12 & Ketersediaan bantuan dan perawatan medis & $-0,091$ & 21 \\
13 & Jalan menuju B29 tersedia dan mudah ditempuh & $-0,052$ & 11 \\
14 & Kualitas jalan menuju B29 & $-0,071$ & 18 \\
15 & Sarana transportasi memadai & $-0,042$ & 6 \\
16 & Terdapat rambu-rambu penunjuk arah yang jelas & $-0,032$ & 4 \\
& B29 & & \\
17 & Kebersihan tempat wisata B29 & $-0,058$ & 13 \\
18 & Kebersihan fasilitas umum (toilet, tempat sampah, & $-0,070$ & 16 \\
tempat ibadah, dll) & Keramahan ojek sepeda motor ke B29 & $-0,045$ & 7 \\
20 & Keramahan masyarakat sekitar B29 & $-0,012$ & 1 \\
21 & Jaminan keamanan pengunjung di wisata B29 & $-0,055$ & 12 \\
\hline
\end{tabular}

Sumber Data : Hasil kuesioner diolah, 2018.

Berdasarkan perhitungan nilai gap terbobot di atas maka dapat disusun keunggulan bersaing pada Destinasi Wisata Alam B29 di Lumajang, maka berikut akan ditentukan 3 (tiga) keunggulan bersaing, sebagai berikut:

Tabel 7. Tiga Keunggulan Bersaing

\begin{tabular}{clc}
\hline Variabel & \multicolumn{1}{c}{ Pernyataan } & Keunggulan \\
\hline \multirow{3}{*}{ Destinasi Wisata B29 } & Keramahan masyarakat sekitar B29 & 1 \\
& Keindahan alam B29 & 2 \\
& Peluang untuk berpetualang di B29 & 3 \\
\hline
\end{tabular}

Sumber Data : Hasil kuesioner diolah, 2018.

Berdasarkan perhitungan nilai gap terbobot di atas maka dapat disusun kelemahan pada wisata alam B29 di Lumajang, maka yang akan menjadi prioritas perbaikan untuk menuju keunggulan bersaing, sebagai berikut:

Tabel 8. Tiga Kelemahan Menjadi Prioritas Perbaikan

Variabel Pernyataan $\quad$ Prioritas




\begin{tabular}{|c|c|c|}
\hline \multirow{3}{*}{ Destinasi Wisata B29 } & Ketersediaan bantuan dan perawatan medis & 1 \\
\hline & $\begin{array}{l}\text { Ketersediaan fasilitas umum (toilet, tempat } \\
\text { sampah, tempat ibadah, dll) }\end{array}$ & 2 \\
\hline & $\begin{array}{l}\text { Ketersediaan listrik, air bersih, jaringan } \\
\text { komunikasi }\end{array}$ & 3 \\
\hline
\end{tabular}

Sumber Data : Hasil kuesioner diolah, 2018.

Salah satu destinasi wisata unggulan di Kabupaten Lumajang dan juga merupakan kebanggaan masyarakat senduro adalah destinasi wisata B29. Keunggulan wisata B29 ini terletak pada keramahan masyarakat, keindahan alam B29 yang terkenal sebagai negeri di atas awan dan peluang untuk berpetualang. Keunikan lokal yang terdiri dari keunikan alam dan keunikan masyarakat menjadi unggulan wisata B29, berdasarkan respon yang dijaring dari persepsi, harapan dan kepentingan masyarakat. Masyarakat yang ramah di desa Argosari Senduro membuat masyarakat menganggapnya sebagai salah satu keunggulan B29. Masyarakat desa Argosari memang sangat ramah dan menyambut dengan baik setiap kali ada wisatawan domestik maupun asing yang berkunjung ke B29 karena menuju wisata tersebut memang harus melalui desa mereka. Keindahan B29 memang tidak diragukan lagi menjadi keunggulan B29 karena alamnya yang benar-benar sejuk dan bisa melihat pemandangan jajaran pegunungan Bromo. Kondisi jalan menuju B29 yang sejuk dan berkelok-kelok nampaknya bisa menciptakan adrenalin bagi pengunjung nya dimana pengunjung juga disajikan pemandangan pertanian yang tertata rapi. Oleh karena itu disarankan agar masyarakat tetap mempertahankan budaya dan sikap ramah mereka dan menjaga kealamiahan kawasan wisata B29 karena itu yang menjadi keunggulan wisata B29.

Berdasarkan persepsi, harapan dan kepentingan masyarakat dan pengunjung di wisata alam B29 di Lumajang ini, penelitian ini mampu menjaring pendapat mereka untuk menentukan apa saja kelemahan yang menjadi prioritas perbaikan atas wisata alam B29 di Lumajang. Prioritas perbaikan ini dimaksudkan untuk memberikan masukan bagi pemerintah maupun masyarakat Lumajang untuk berbenah agar produk dan wisata unggulan mereka menjadi lebih baik dan sesuai persepsi, harapan dan kepentingan masyarakat. Sarana dan prasarana di kawasan B29 juga menjadi prioritas perbaikan berdasarkan persepsi, harapan dan kepentingan masyarakat. Ketersediaan bantuan dan perawatan medis, ketersediaan fasilitas umum yang memadai, ketersediaan listrik, air bersih dan jaringan komunikasi yang baik, menjadi pilihan pengunjung untuk kondisi yang harus diprioritaskan untuk diperbaiki. Keberadaan puncak B29 yang cukup tinggi seharusnya tidak menjadi penghalang bagi masyarakat untuk menyediakan semua sarana dan prasarana pendukung B29 yang lebih baik. Oleh karena itu disarankan bagi pengelola wisata B29 untuk menyediakan sarana prasarana tersebut dengan kondisi yang lebih baik. Pos kesehatan nampaknya juga diperlukan untuk dibangun di kawasan ini, mengingat jalan menuju puncak B29 yang berkelokkelok dan kondisinya yang cukup dingin, bisa menimbulkan hal-hal yang tidak diinginkan seputar kesehatan dan keselamatan pengunjungnya.

\section{KESIMPULAN}

Berdasarkan pembahasan yang telah dilakukan serta kajian hipotesis yang dikembangkan dalam penelitian ini, maka dapat di jelaskan mengenai kesimpulan dari pelaksanaan penelitian ini sebagai berikut : (1) Fasilitas umroh tidak mempunyai pengaruh yang signifikan terhadap persepsi jamaah dalam memilih jasa umroh (2) Biaya perjalanan umroh memiliki pengaruh yang signifikan terhadap persepsi jamaah dalam memilih jasa umroh. (3) Secara simultan fasilitas dan biaya mampu memberikan pengaruh terhadap persepsi yang dimiliki jamaah dalam memilih umroh Pada PT. UDA CS HOLIDAYS INDONESIA.

\section{DAFTAR PUSTAKA}


Chulaifi, M, I., Endang, S. (2018). Pengaruh Kualitas Pelayanan, Persepsi Harga Dan Kepercayaan Terhadap Kepuasan Konsumen Jasa Travel Umrah Dan Haji Pada PT. Sebariz Warna Berkah Di Surabaya. Jurnal Hasil Penelitian LPPM Untag Surabaya. 03, 01. Diakses dari http://jurnal.untag-sby.ac.id/index.php/jhp17/issue/view/144

Fadillah, L. (2019). Strategi Dan Manajemen Travel Haji Dan Umroh (Studi Analisis Persaingan Travel Haji Dan Umroh Kota Medan Dalam Pelayanan dan Kualitas Untuk Meningkatkan jumlah Konsumen. Al-Muamalat : Jurnal Hukum Ekonomi Syariah. 4, 01. 1-24. Diakses dari https://journal.iainlangsa.ac.id/index.php/muamalat/article/view/775

Ghozali, I. (2011). Aplikasi Analisis Multivariate dengan program SPSS. Semarang: Universitas Diponegoro.

Hurriyati, R. (2012). Bauran Pemasaran dan Loyalitas Konsumen. Bandung: Alfabeta.

Kemenag. (2019). Pencarian PPIU (Penyelenggara Perjalanan Ibadah Umrah). tulisan pada https://simpu.kemenag.go.id/home/travel.

Kotler, P. (2013). Dasar-dasar Pemasaran. Jakarta: Intermedia.

Lempoy, N, C., Silvya, L, M., Sjendry, S, R, L. (2015). Pengaruh Harga, Lokasi, Dan Fasilitas Terhadap Keputusan Menggunakan Jasa Taman Wisata Toar Lumimuut (Taman Eman) Sonder. Jurnal EMBA: Jurnal Riset Ekonomi, Manajemen, Bisnis dan Akuntansi. 3, 1. 1072-1083. DOI : https://doi.org/10.35794/emba.v3i1.7867

Lupiyoadi, R. (2012). Manajemen Pemasaran Jasa Teori dan Praktik. Jakarta: Salemba Empat.

Memah, D., Altje, T., Paulina V, R .(2015). Pengaruh Strategi Promosi, Harga Lokasi Dan Fasilitas Terhadap Keputusan Pembelian Rumah Di Citraland Manado. Jurnal EMBA. 3, 1. 1263-1273. DOI : https://doi.org/10.35794/emba.v3i1.8285

Nityasari, A. H., Sutopo. (2013). Analisis Pengaruh Kualitas Pelayanan Terhadap Kepuasan Pengguna Jasa Jamaah Umroh Tahun 2010-2012 (Studi Kasus Pada PT Fatimah Zahra Semarang). Diponegoro Journal Of Management. 1, 2. 82-90. Diakses dari https://ejournal3.undip.ac.id/index.php/djom/article/view/9011

Raharjaputra, H, S. (2011). Manajemen Keuangan dan Praktis. Jakarta: Salemba Empat.

Ramadhani, N, H. (2017). Pengaruh Kualitas Pelayanan Terhadap Kepuasan Pelanggan PT. Basmatour \& Travel. Diakses dari Universitas Muhammadiyah Malang, Institusional Repository, http://eprints.umm.ac.id/34747/.

Sugiyono. (2016). Metode Penelitian Kuantitatif Kualitatif dan H\&D. Bandung: Alfabeta.

Tjiptono, F. (2012). Pemasaran Strategik. Yogyakarta: ANDI. 